\title{
Analysis of patterns in larval walleye pollock Theragra chalcogramma survival and wind mixing events in Shelikof Strait, Gulf of Alaska
}

\author{
Kevin M. Bailey ${ }^{1}$, S. Allen Macklin ${ }^{2}$

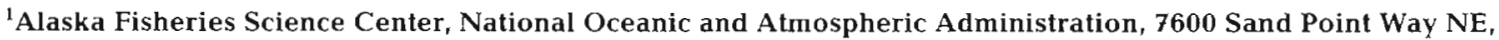 \\ Seattle, Washington 98115-0070, USA \\ ${ }^{2}$ Pacific Marine Environmental Laboratory, National Oceanic and Atmospheric Administration, 7600 Sand Point Way NE, \\ Seattle, Washington 98115-0070, USA
}

\begin{abstract}
This study examines the possibility that wind mixing in Shelikof Strait, Gulf of Alaska, is a critical factor for larvae of walleye pollock Theragra chalcogramma. The abundances of walleye pollock larvae hatched on a given day and surviving through the early feeding stage were determined by in situ sampling and otolith analysis for 1983 and 1985 to 1991. Periods of anomalously low or high larval survival were determined by comparing observed first-feeding date distributions of survivors sampled in late May surveys with expected first-feeding date distributions from a model utilizing information on spawning time and abundance, measured egg mortality, assumed larval mortality, and survey date. The cube of the wind speed represented daily estimates of mixing for the same years; wind speeds were determined from gridded sea-level pressure data using a geotriptic wind model. When the resulting daily distributions of larval abundance and mixing were compared, 2 patterns emerged: (1) strong wind mixing events during the first-feeding period were associated with periods of lower than expected larval survival, and (2) periods of higher than expected larval survival were associated with calm wind periods often bracketed by strong mixing. The results indicate that over the $8 \mathrm{yr}$ of observation strong mixing events during the first-feeding period were detrimental to survival of pollock larvae.
\end{abstract}

KEY WORDS: Walleye pollock - Theragra chalcogramma Hatch date - Wind mixing

\section{INTRODUCTION}

Wind-driven turbulence and transport are 2 processes hypothesized to affect the survival of marine fish larvae (Lasker 1975, Norcross \& Shaw 1984); however, strong evidence linking larval survival to wind condition remains elusive. In the case of northern anchovy Engraulis mordax larvae, the number of strong wind events was related to the annual instantaneous mortality rate (Peterman \& Bradford 1987); but, without evidence relating specific wind events to survival patterns, the linkage between the 2 processes is not well established. Wind-related transport is also believed to influence the successful recruitment of marine invertebrate species (Roughgarden et al. 1988, Farrell et al. 1991), and marine fish species (e.g. Bailey 1981), but evidence of event-scale processes is lacking.
Wind mixing and associated turbulence can be either beneficial or detrimental for larval survival (Davis et al. 1991). It can increase contact rates with prey (Rothschild \& Osborn 1988, Sundby et al. 1989, MacKenzie \& Leggett 1991), and mild turbulence can increase larval feeding rates (Sundby et al. 1989). Wind-induced mixing also can inject nutrients into the upper water column (Huntsman \& Barber 1977) promoting primary production (Raymont 1980) and copepod egg production (Kiorboe et al. 1988). Phytoplankton production pulses have been linked to periods of successful settlement of a rocky reef fish Heteroclinus sp., presumably through enhanced feeding success and early larval survival (Thresher et al. 1989). However, strong mixing can disrupt layers of prey (Lasker 1975, Lough 1984, Wroblewski \& Richman 1987, Owen 1989), depress photosynthesis (Huntsman \& Barber 1977) or timing of 
the spring bloom (Raymont 1980) and consequent timing of naupliar production (Diel \& Tande 1992). Coombs et al. (1992) observed that both sprat eggs and larvae and their microzooplankton prey were more dispersed and deeper in the water column when it was well mixed compared to when it was stratified. On the other hand, moderate wind mixing events did not appear to disrupt concentrations of larval anchory prey, but did appear to disperse the larvae themselves (Mullin et al. 1985), implicating a direct behavioral response of the larvae. The active avoidance of turbulence by larvae or their deeper depth distribution due to mixing can have a great effect on feeding rates, largely because of the detrimental effects of reduced light intensity on the ability of larvae to search for and capture prey (Heath 1989). Periods of strong winds have also been linked to reduced growth rate of Atlantic menhaden Brevoortia tyrannus and Atlantic herring Clupea harengus L. larvae (Heath 1989, Maillet \& Checkley 1991). Avoidance of turbulence by walleye pollock Theragra chalcogramma larvae has been observed in laboratory experiments (Olla \& Davis 1990).

The major spawning area for walleye pollock in the Gulf of Alaska is in the southwestern portion of Shelikof Strait (Fig. 1). Historically, about $88 \%$ of walleye pollock eggs found in the western Gulf of Alaska are caught in Shelikof Strait (Kendall \& Picquelle 1990), although as the relative abundance of this population has declined in recent years, this percentage is expected to decrease. Allozyme (Grant \& Utter 1980) and mtDNA analyses (Mulligan et al. 1992) support the concept that pollock spawning in Shelikof Strait are a separate stock from the larger Bering Sea populations, but there could be some mixing. In Shelikof Strait, spawning occurs near bottom, mostly during a 2 wk period centered in early April (Kendall \& Picquelle 1990). Hatching larvae rise in the water column and are transported southwestward (Incze et al. 1989); they reach first-feeding stage about 3 wk after spawning and reside in the upper water column ( 0 to $60 \mathrm{~m}$ ). Their habitat is a storm-prone area (Wilson \& Overland 1986). The quasi-periodic strong winds associated with the passage of storms through Shelikof Strait are further accelerated by air mass interactions with coastal mountains (Lackmann \& Overland 1989). Because of their limited spawning period, total survival of larval stages of Shelikof Strait pollock is likely to be influenced by periodic and stochastic fluctuations in the environment. The influence of winds during the larval period apparently persists through subsequent life stages, as Megrey et al. (in press) have correlated the abundance of juvenile walleye pollock recruits to local wind conditions during larval life.

In this paper we describe the relationship between periods of low and high wind events and daily survival patterns of larval walleye pollock. In our analysis the patterns in the observed daily first-feeding date distribution (hatch dates lagged forward 5 d) of successful surviving larvae and expected distributions were compared to an index of local wind mixing. We believe that our data, while not specifically addressing how wind events influence secondary processes such as prey productivity and density, do establish a coherence between patterns of larval survival and winds on a timescale that points to a linkage between the processes.

\section{METHODS}

Walleye pollock larvae were sampled from ichthyo plankton surveys conducted by Fisheries Oceanography Coordinated Investigations (FOCI) in the western Gulf of Alaska extending from Shelikof Strait to the Shumagin Islands area (downstream of the spawning locale) during May and June in 1983 and 1985 to 1991. Survey information is summarized in Table 1. Methods for collection of walleye pollock larvae are described in Dunn \& Rugen (1989) and 
Table 1 Theragra chalcogramma. Summary of survey, annual egg production and mortality information. Egg mortality \pm SE is from Picquelle \& Megrey (1993) and Picquelle (pers. comm.). Total annual number of eggs spawned is from A. Hollowed \& S. Picquelle (pers. comm.). SST: sea surface temperature

\begin{tabular}{|c|c|c|c|c|c|c|c|}
\hline Year & $\begin{array}{c}\text { Mean } \\
\text { survey date }\end{array}$ & $\begin{array}{l}\text { No. of } \\
\text { stations }\end{array}$ & $\begin{array}{c}\text { No. of } \\
\text { age samples }\end{array}$ & $\begin{array}{c}\text { No. of } \\
\text { length samples }\end{array}$ & $\begin{array}{c}\text { Mean } \\
\text { Apr/May SST }\left({ }^{\circ} \mathrm{C}\right)\end{array}$ & $\begin{array}{l}\text { Total annual } \\
\text { eggs spawned }\end{array}$ & $\begin{array}{l}\text { Annual egg } \\
\text { mortality }\left(\mathrm{d}^{-1}\right)\end{array}$ \\
\hline 1983 & 24 May & 61 & 109 & 608 & $5.21 / 6.21$ & $3.95 \times 10^{14}$ & $0.21^{\mathrm{d}}$ \\
\hline 1985 & 7 May & 141 & 25 & 208 & $3.63 / 4.93$ & $2.29 \times 10^{17}$ & $0.160 \pm 0.028$ \\
\hline 1986 & 5 May & 54 & 36 & 380 & $3.69 / 4.46$ & $1.24 \times 10^{14}$ & $0.21^{\mathrm{a}}$ \\
\hline 1987 & $21 \mathrm{May}$ & 42 & 204 & 394 & $4.09 / 6.27$ & $1.05 \times 10^{14}$ & $0.212 \pm 0.025$ \\
\hline 1988 & 22 May & 66 & 309 & 857 & $3.79 / 6.13$ & $0.86 \times 10^{14}$ & $0.289 \pm 0.025$ \\
\hline 1989 & $1 \mathrm{Jun}$ & 89 & 207 & 1292 & $3.36 / 4.83$ & $0.97 \times 10^{14}$ & $0.174 \pm 0.016$ \\
\hline 1990 & 1 Jun & 114 & 143 & 1594 & $3.66 / 5.47$ & $0.94 \times 10^{14}$ & $0.148 \pm 0.013$ \\
\hline 1991 & 22 May & 75 & 117 & 308 & $3.44 / 4.87$ & $1.56 \times 10^{14}$ & $0.222 \pm 0.026$ \\
\hline
\end{tabular}

Bailey \& Spring (1992). Late May sampling gear included $60 \mathrm{~cm}$ bongo and $1 \mathrm{~m}$ Tucker nets. These are efficient samplers of pollock larvae of 6 to $18 \mathrm{~mm}$ length; there are no significant differences in catches between these nets or day/night differences in length distribution of catches (Hinckley et al. 1993, Shima \& Bailey 1994).

Larvae for otolith ageing were removed from the cod end after retrieval and preserved in $95 \%$ ethanol. Ageing techniques are described in Yoklavich \& Bailey (1990). Previous studies of larval walleye pollock have demonstrated that increments are deposited daily (Nishimura \& Yamada 1984, Bailey \& Stehr 1988).

Hatch date distributions were calculated following methods of Yoklavich \& Bailey (1990) and Hinckley et al. (1993), modified slightly as follows. Age-length keys were generated and applied to the larger lengthfrequency samples to generate an age distribution for each station. Larval lengths from different fixatives were standardized to live prefixed lengths. Because surveys are not synoptic and larvae are collected throughout the survey period, ages and lengths of larvae were standardized to the mean survey date for each cruise utilizing a growth model (Brown \& Bailey 1992). The pollock growth model was fitted to each year's agelength data. Hatch dates were calculated from standardized age and mean survey date. Standardized numbers were determined from the area represented by each station, and hatch date abundances were summed over all stations. The variance in abundance at each hatch date was estimated. In general the modifications used in the present study had minor effects on the hatch date distributions compared with the previous methods of Yoklavich \& Bailey (1990). The small number of age samples for 1985 and 1986 was a concern. We tested the effects of using an inverse growth model to derive ages from lengths and the resulting effects on hatch date distributions were not remarkably different, so we utilized the age-length keys throughout.
There are several problems in interpreting hatch date information. High larval mortality makes interannual comparison of larval abundance indices particularly sensitive to differences in the timing of surveys, and subject to bias. For example, a 5 d difference in collection date would result in a $40 \%$ difference in abundance due to mortality if all other parameters are constant (assuming a conservative and constant larval mortality rate of $0.1 \mathrm{~d}^{-1}$, same initial abundance and spawn date). Therefore survey date needs to be considered in formulating larval abundance indices. Next, because younger larvae have been exposed to sources of mortality for a shorter duration than older larvae, the relative abundances of younger and older larvae are biased towards younger animals. Finally, larval abundance indices must be partly dependent on the initial numbers of eggs spawned. These issues were addressed by modeling the expected number of larvae from each daily cohort present during annual surveys while accounting for initial egg production $\left(N_{i, t_{0}}\right)$, annual estimates of egg mortality $\left(m_{1}\right)$, temporal distribution of spawning, and an average larval mortality $\left(m_{2}\right)$, such that:

$$
N_{l, t_{\mathrm{S}}}=N_{1, t_{0}} \mathrm{e}^{-\left\{14 m_{1}+m_{2}\left[t_{\mathrm{S}}-\left(t_{0}+14\right)\right]\right\}}
$$

where $N$ is the abundance of cohort $i$ sampled on mean survey date $t_{\mathrm{s}}$ (in day of the year), $t_{0}$ is spawn date, and $m_{1}$ operates over the $14 \mathrm{~d}$ duration of egg stage. Total seasonal egg production,

$$
\sum_{i=1}^{n} N_{j, t_{0}}
$$

from the Shelik of Strait population was estimated from mature adult biomass and fecundity (from A. Hollowed pers. comm.). Spawning was assumed to fit a bellshaped curve over time, and it was modeled by an equation for the cosine curve given in Picquelle \& Megrey (1993). The modeled spawning season had a duration of $48 \mathrm{~d}$ with a peak on 8 April. Annual esti- 
mates of egg mortality reported in Picquelle \& Megrey (1993) and from Picquelle (pers. comm.) were determined from annual egg surveys in 1985, 1987, 1988, 1989, 1990 and 1991. Although an estimate was available for 1986, it was less than half of any other value and thus seemed unrealistically low. For 1986 and 1983 (no egg survey) we used a mean egg mortality $\left(0.21 \mathrm{~d}^{-1}\right)$ from the years 1985 to 1989 . Use of a constant egg development time is a conservative assumption since the exact temperature at depths where eggs are developing is unknown and changes as eggs rise in the water column. Over the range of bottom water temperatures observed, the egg development time is expected to vary by less than $1 \mathrm{~d}$ (Yoklavich \& Bailey 1990). As we later discuss, shifts in the spawning distribution (and likewise hatching distribution) by up to $5 \mathrm{~d}$ have a minimal effect on our results. Larval mortality $\left(m_{2}\right)$ was assumed to be age-dependent after the following stepped schedule (Yoklavich \& Bailey 1990):

$$
\begin{array}{r}
\text { age }>53 \mathrm{~d}, m_{2}=0.01 \\
42 \mathrm{~d}<\text { age }<54 \mathrm{~d}, m_{2}=0.03 \\
27 \mathrm{~d}<\text { age }<43 \mathrm{~d}, m_{2}=0.06 \\
14 \mathrm{~d}<\text { age }<28 \mathrm{~d}, m_{2}=0.08 \\
0 \mathrm{~d}<\text { age }<15 \mathrm{~d}, m_{2}=0.10
\end{array}
$$

Since other parameters are measured, differences in observed and expected birth date distributions result from interannual variations in spawning time or shape of the spawning curve from the assumed value or deviation of larval mortality from the assumed mortality schedule.

Recently hatched pollock larvae live on their yolk and are located deep (150 to $300 \mathrm{~m})$ in the water column where they are not vulnerable to wind conditions for the first few days before they rise into the mixed layer (above $40 \mathrm{~m}$ ). Larvae at typical in situ temperatures of 4 to $6^{\circ} \mathrm{C}$ begin feeding 4 to $7 \mathrm{~d}$ after hatching, although hypothetically, situations that set up good or poor feeding conditions can be influenced by wind conditions several days prior to feeding. To test the hypothesis that winds and larval survival were correlated, we stepped the hatch date numbers forward by $5 \mathrm{~d}$ to simulate when most larvae would achieve first-feeding status (hence our use of the term first-feeding distribution) and when they would be in the upper $40 \mathrm{~m}$ of the water column where they are vulnerable to turbulence and transport conditions.

Daily computed wind conditions were compared with observed versus expected larval cohort abundances over the period of the expected hatch date distribution, excluding the first and last 10\% (the tails) of the total expected spawning distribution, or for the latter criterion, $5 \mathrm{~d}$ before the end of survey, whichever came first. It was assumed that pollock larvae in the excluded range are comprised of relatively few age samples, and would not accurately represent the true age distribution.
Surface wind speed was estimated by applying a geotriptic force balance (Johnson 1966) to gridded distributions of sea-level pressure, produced and digitized twice daily by the National Meteorological Center. The geotriptic model was tuned using previous comparisons of observed surface winds in the study area (Macklin et al. 1993). Modeled winds are well correlated $(r \approx 0.8)$ with actual surface winds for sampling periods longer than $2 \mathrm{~d}$ during the spring (Macklin et al. 1993).

Using a model of the influence of atmospheric forcing on turbulence in the oceanic mixed layer, Klein \& Coste (1984) showed that 2 wind processes dominate: (1) the downward transport of turbulent kinetic energy from surface processes, and (2) the interaction of wind stress with surface currents. The relative magnitude of these contributions depends on the depth of the mixed layer, the wind velocity, and the current velocity.

The production of turbulent kinetic energy by wind mixing is (Niiler 1977):

$$
\mu \cdot \cdot^{3}=\left(\frac{\tau}{\rho}\right)^{3 / 2}
$$

where $\tau$ is the surface momentum flux (stress) and $\rho$ is the air density. Because sea-surface wind stress is generally proportional to the square root of the wind speed, mixing is proportional to the cube of the wind speed. Thus wind mixing employs the higher moment of wind speed, and wind speed cubed is used as the forcing variable in this discussion.

For time series analysis of the first-feeding distribution, the data were detrended using the residuals from a $9 \mathrm{~d}$ running mean. The residuals were smoothed using a $3 \mathrm{~d}$ running mean. Detrending by first-order differencing was also tested.

\section{RESULTS}

Time series analyses of the first-feeding date distributions (hatch date distribution lagged forward $5 \mathrm{~d}$ to first feeding) show an apparent correspondence between strong wind events and negative residuals from the time series model, and positive residuals during calm wind periods (Fig. 2). However, the time series residuals do not reflect changes in the magnitude of spawning and survival, only changes in the trend compared with previous or surrounding values. Thus, we have analysed our empirical data against modeled results simulated from initial estimates of annual egg production and mortality, and average conditions for spawning distribution and larval mortality (spawning/survival model). We note, however, that a comparison between the time series residuals (and note here 

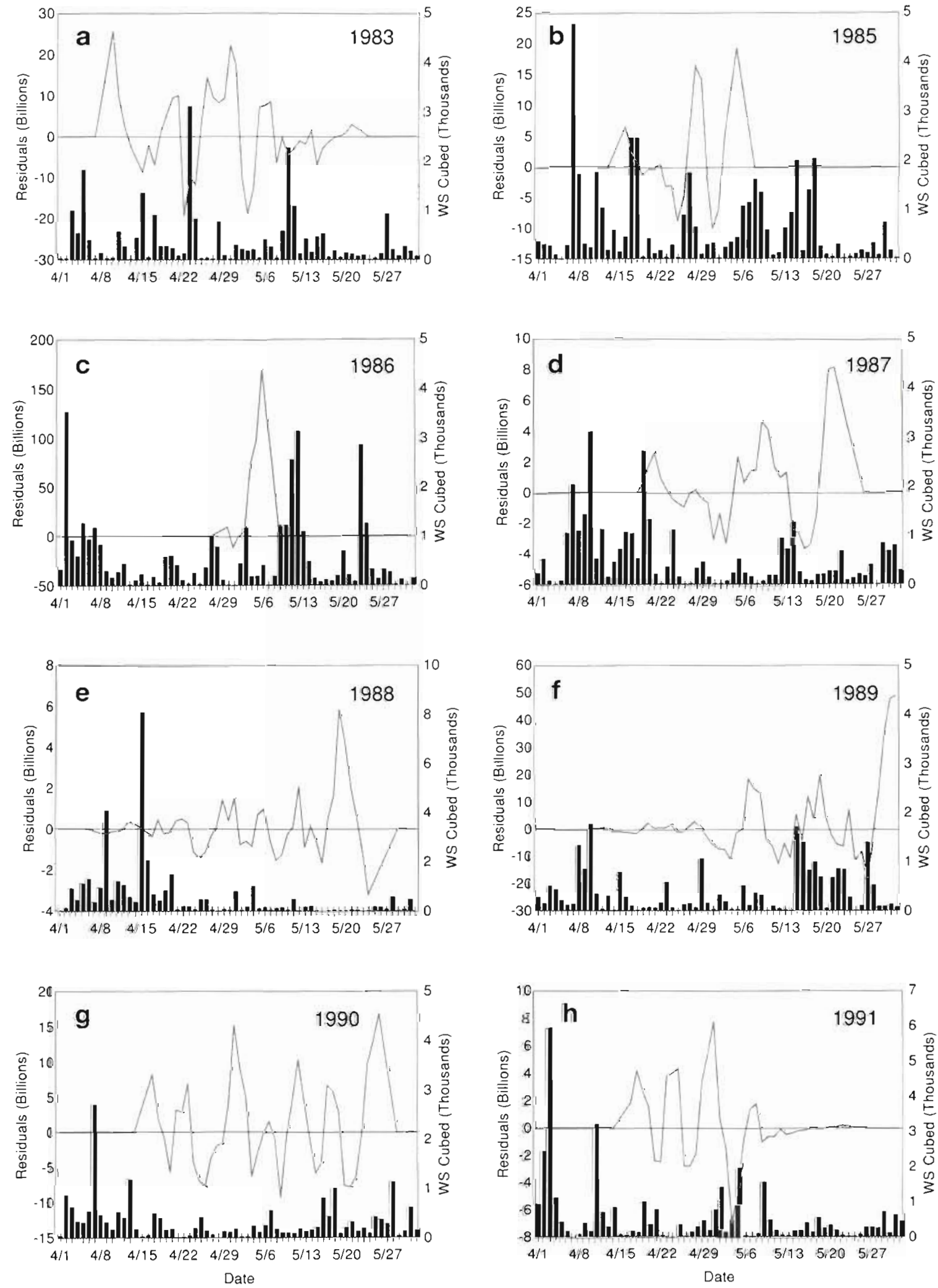

Fig. 2. Theragra chalcogramma. Detrended and smoothed time series based on residuals from the $9 \mathrm{~d}$ running mean of firstfeeding date (hatch date +5 d) distribution of larvae, sampled in mid- to late May surveys (line) compared with an index of wind mixing (bars, in $\mathrm{m}^{3} \mathrm{~s}^{-3}$ ). The residuals are smoothed with a 3 d running mean. (a) 1983, (b) 1985, (c) 1986, (d) 1987, (e) 1988, (f) 1989, (g) 1990, (h) 1991 WS: wind speed; dates are given in the format Month/Day 

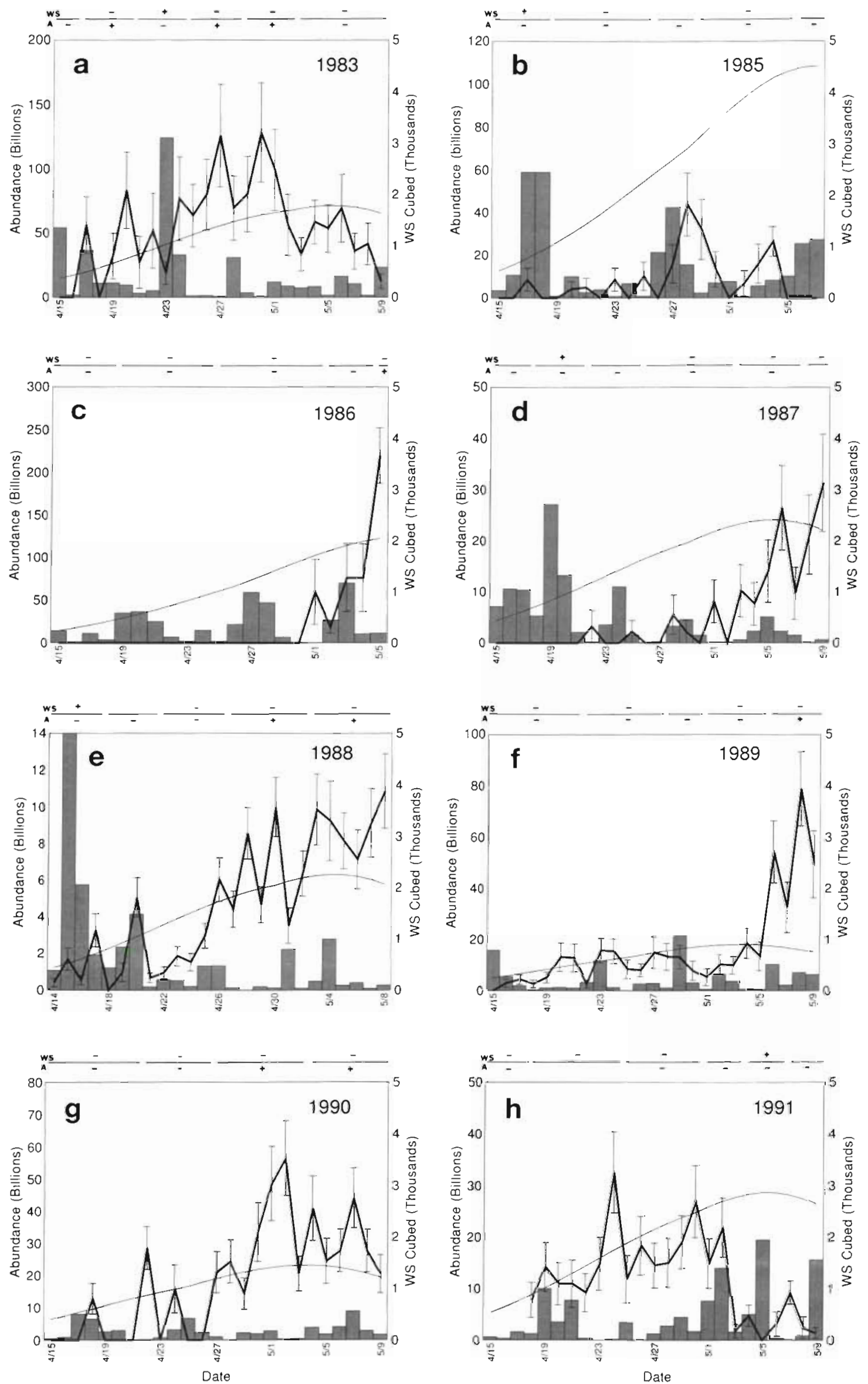
that similar results are obtained from differencing techniques) and the residuals from observed versus expected results from the spawning/survival model indicates highly significant correlations $(p<0.005)$ for every year except $1985(p=0.14)$; in 1985 there was nearly a $1: 1$ relationship between the 2 variables (slope $=0.95$ ) but the scatter around the line was high.

The number of observed larvae was compared (Fig. 3a to h) with the expected number of larvae based on the spawning/survival model (note the expected distributions are not bell-shaped because of the varying duration that each daily cohort experienced mortality between the time that it hatched and was sampled). For most years, the observed number of larvae surviving was generally lower than the expected number, suggesting that the mortality rates for pollock larvae are usually higher than the expected values used here. Examination of the residuals of each year for the first $30 \mathrm{~d}$ from the first-feeding date does not indicate any distinct trend for the residuals to increase with time passed from the first-feeding date to sampling date (Fig. 4). However, it is notable that some years have persistently positive residuals (1988 and 1989) and some have persistently negative values (1985 and 1986). Since the larval mortality schedule was adapted from 1987 (albeit for a different time interval) the residuals from that year are fairly close to zero.

The association between periods of strong winds and observed versus expected larval survival was tested using contingency tables. We did not use correlation analysis because we did not expect a direct correlation, nor would we expect all weak wind periods to result in high larval survival because of the multitude of factors influencing larval mortality. We therefore tested whether calm and turbulent periods were associated with weak or strong larval survival by classifying the data into 42 intervals centered primarily on 3 to $4 \mathrm{~d}$ periods around strong to medium wind mixing conditions, as defined below. Periods of low wind mixing conditions were further subdivided into 3 to $7 \mathrm{~d}$ intervals if significant survival events occurred within them. High and low survival events within a period balanced out. All exceptionally high and low larval periods were represented by more than 1 daily cohort, with the exception of 3 significant survival events occurring at the ends of the distribution. Strong,

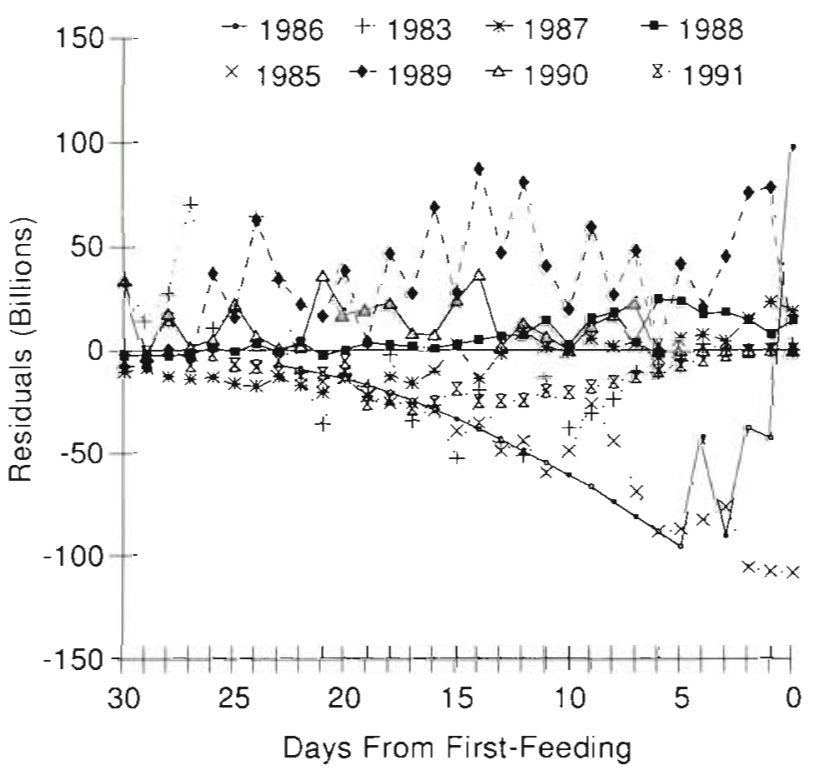

Fig. 4. Theragra chalcogramma. Residuals of the observed firstfeeding distribution subtracted from the expected distribtion based on a spawning/mortality model. Residuals are shown from $30 \mathrm{~d}$ after larvae have attained first-feeding readiness to the day of first-feeding readiness (hatch date +5 d)

medium and low wind mixing periods were defined as those with the cube of the wind speed $>2000,1000$ to 1999, and < $999 \mathrm{~m} \mathrm{~s}^{-3}$, respectively. Strong, medium and weak hatch periods were defined as those with $1 \mathrm{SD}$ greater than expected abundances, within $\pm 1 \mathrm{SD}$, and $<1 \mathrm{SD}$, respectively. Out of 9 high larval survival periods, all occurred during low wind conditions; out of 5 strong wind periods, all were associated with low larval survival (Table 2). To reduce the number of cells with frequency $<5$ observations, existing cells were combined to form $2 \times 2$ contingency tables. Fisher's exact test was employed because 1 cell had zero observations ( $Z a r$ 1984). To test the hypothesis that high survival periods are associated with low winds, the low and medium larval survival cells and high and medium wind cells were combined. The null hypothesis of no association was rejected $(p=0.016)$. A second test was used to examine the association of low survival periods with strong to medium winds by combining medium and high larval survival periods and medium and high wind mixing periods. The null hypothesis of no association was rejected $(\mathrm{p}=0.003)$.

Fig. 3. Theragra chalcogramma. Observed (heavy solid line, vertical lines are standard deviations) first-feeding date (hatch date + 5 d) distribution of larvae sampled in mid- to late May surveys compared with expected distributions (light solid line) based on a spawning/mortality model. Deviations of observed to expected distributions are compared with an index of wind mixing (bars, in $\mathrm{m}^{3} \mathrm{~s}^{-3}$ ) on the first-feeding date. (a) 1983, (b) 1985, (c) 1986, (d) 1987, (e) 1988, (f) 1989, (g) 1990, (h) 1991. Interval used for analysis excludes the first and last $10 \%$ of the expected spawning distribution (see text). Periods of high/low ( $+/-$ ) winds (WS) and larval abundance (A) used in analyses are shown at the top. Medium periods are left blank. Dates are given in the format Month/Day 
Table 2 . Theragra chalcogramma. $3 \times 3$ contingency table of low-high wind mixing and larval survival periods. Combinations of cells were used to make the $2 \times 2$ tables discussed in the text

\begin{tabular}{|lrccr|}
\hline \multirow{2}{*}{ Winds } & \multicolumn{4}{c}{ Larval survival } \\
& Low & Medium & High & $\Sigma$ \\
\hline Low & 16 & 2 & 9 & 27 \\
Medium & 10 & 0 & 0 & 10 \\
High & 5 & 0 & 0 & 5 \\
$\Sigma$ & 31 & 2 & 9 & 42 \\
\hline
\end{tabular}

A further test, Cox's test for correlation between instants of occurrence (Cox 1955), was used to test if high or low wind mixing conditions were coincident with low or high larval survival periods, respectively. Since all 15 medium/strong wind events were coincident with low larval survival periods, the association was high (estimated probability $=1.00, t$-test for significant difference from zero, $p=0.000$ ). The probability that low winds would produce coincident high larval survival periods was low $(0.137)$, but significantly different from zero ( $t$-test, $\mathrm{p}<0.05)$

Another test was used to determine whether the mean wind mixing differed between good and poor survival periods. For this analysis protracted and exceptional high and low larval survival periods were defined as those when the $3 \mathrm{~d}$ running means of observed hatch date abundances were more than $1 \mathrm{SD}$ (using the running standard deviations) from the expected abundances. The hypothesis that mean wind mixing during higher than expected survival periods was lower than that during lower than expected survival periods was tested. Mean wind mixing during high survival periods was significantly less (mean = $200.6, \mathrm{SE}=40.2$ ) than that during low survival periods $($ mean $=534.0, \mathrm{SE}=86.7)(t$-test assuming unequal variances; $p=0.0004$ ).

The assumption of a fixed spawning date (maximum egg production on 8 April) versus a variable spawning date had little effect on designation of significantly high or low larval survival relative to expected numbers. The assumed distribution of spawning was shifted by $\pm 5 \mathrm{~d}$ until the absolute value of observed versus expected residuals were minimized. A $10 \mathrm{~d}$ variation in spawning time was consistent with reasonable expectations (Picquelle \& Megrey 1993, A. Kendall pers. comm.). The effect of sliding the spawning curve forwards or backwards is easily visualized from Fig. 3a to $h$. (Note that the cutoff dates for the upper $10 \%$ of the spawning tails will also change accordingly.) Only 1 period designated as significantly higher or lower than expected changed its classification, and that was from high to medium. Two periods that were rated as average survival periods not different from the expected values became high survival periods with the variable spawning distribution. However, these were during periods of very low winds, and the results are not inconsistent with our conclusions.

\section{DISCUSSION}

In our study, we observed a significant association between wind mixing and the survival of pollock larvae. These findings were consistent with the hypotheses that strong wind mixing events during the period of first-feeding readiness disrupt larval survival and calm periods favor larval survival. Recruitment of animals with planktonic stages is a complex process, and we would not expect 1 factor at a specific life history stage to dominate survival processes in all cases (Wooster \& Bailey 1989). Although all strong mixing events resulted in poorer than expected larval survival, not all calm periods resulted in higher than expected larval survival. Other factors may have regulated larval survival during these periods (e.g. predation), or some other conditions may not have been suitable for prey production and feeding.

Caution is necessary when interpreting these results, for the following reasons. First, absolute numbers of larvae will vary greatly due to slight differences in the timing of surveys, even given conservative estimates of mortality. Therefore, in this paper we analyzed the observed versus expected larval numbers. Differences in observed versus expected numbers of daily cohorts of larvae can be due to deviations from expected spawning time, pulses of spawning, variations in the spatial distribution of larvae relative to the survey area, or differences in mortality of larvae from expected values. We demonstrated that our results were not sensitive to moderate variations in spawning time, but spawning pulses could affect the shape of the hatch date distributions. Furthermore, our results are consistent with results from a time series approach, where deviations from the seasonal trend are examined. Examination of hatch dates from juveniles is desirable because the mortality has stabilized, but there is the likelihood of intervening events which would obscure prior relationships, possible shifts in the distribution due to size-related mortality, and a decrease in ageing precision. Second, hatch dates can be truncated if either end of the larval age distribution is not adequately sampled since there is often an alongshore age gradient (Kim \& Kendall 1989). All surveys appeared to adequately cover the distribution of larvae (see Fig. 1; additional larval and survey distributions in Yoklavich \& Bailey 1990, Hinckley et al. 1993; expected distributions in Kendall \& Picquelle 1990), except in 1985 when many larvae were located to the 
northeast of the survey area (Fig. 5 in Incze et al. 1989, discussed below). In 1987 (the year with the minimum survey area; Fig. 1) the hatch date distribution of the May survey was not significantly different from a much more extensive survey conducted later in June and July (Brown \& Bailey 1992), indicating that the age distribution was well sampled. Finally, hatch date distributions can also be truncated if the survey period occurred before hatching was completed. We accounted for the latter problem by analyzing over the period from when $10 \%$ of the larvae were expected to achieve first feeding to $5 \mathrm{~d}$ before the end of the survey, or when $90 \%$ of larvae were expected to achieve first feeding, whichever came first.

Anomalous conditions occurred during 1985 and 1989 that are of interest. As mentioned above, the observed larval abundances for 1985 were far below expected levels in the study area. A more extensive survey later in the year indicated that many pollock larvae were distributed northeast of the study site, presumably arriving there by anomalous transport conditions. Unfortunately, age samples were not available from the region. We believe that this anomalous condition does not affect our conclusions about wind mixing effects on larvae in the Shelikof Strait region. In this latter case, peaks in backcalculated first-feeding date distributions occurred during lulls in the wind mixing, and strong to moderate wind events corresponded to low to moderate observed larval abundance. Examination of winds near the center of larval abundance in 1985 indicates that larvae were in a relatively benign environment, as the storm centered on 27 April was a minor event northeast of Kodiak Island. In 1989, the spawning period appeared to be protracted, as hatch date distributions extended beyond the expected end point. This circumstance is difficult to explain, but it also does not affect our conclusions during the interval of interest.

Effects of turbulence on availability of prey to pollock larvae are likely to be an important factor in the observed association between wind conditions and the survival of pollock larvae. Nutritional condition of walleye pollock in the Shelikof region, as reflected by nucleic acid content, has been linked to naupliar concentrations and larval gut contents, implicating the importance of prey levels to larval condition and growth (Canino et al. 1991). The role of eddies in water column stratification may be a critical aspect of wind mixing and larval survival. For example in early spring 1989, a patch of walleye pollock larvae experienced an enhanced prey and feeding situation relative to surrounding water. Subsequently this patch was found to have been associated with an eddy (Bograd et al. in press). The eddy was anticyclonic and relatively fresh, thus the effects of wind mixing on vertical stability is expected to be less (Price et al. 1986).
Early spring represents a transition in the mixedlayer depth since windy periods which stir the mixed layer and keep it deep (>150 m) decrease and solar radiation and freshwater runoff begin to enhance thermal stratification and the salinity gradient. By June, stratification is strong and the mixed-layer depth is about $15 \mathrm{~m}$. There is some support in our data indicating that moderate wind mixing events generally resulted in lower than expected larval survival in early spring and in cold years when stratification of the water column was probably weak. For example, larval survival was relatively poor during moderate mixing events early in the year (e.g. 15 to 17 April 1987) or in cold water years such as 1985 and 1986 (Table 1; mean May sea surface temperature 1983 to $1991=5.40^{\circ} \mathrm{C}$ ). Moderate wind events later in the year ( 2 to 4 May 1986) or in warm years (19 to 21 April 1988) did not appear to disrupt larval survival patterns. Furthermore, high survival periods occurred relatively early in the season in the warm year of 1983 .

Transport of larvae from the survey area is also a mechanism that could interrupt periods of larval production, as larvae advected to the southwest can become entrained in the strong (up to $175 \mathrm{~cm} \mathrm{~s}^{-1}$ ) Alaska Stream, where they could be lost to the population. Transport derived from currents measured at 3 locations in the Alaska Coastal Current (ACC) during 1991 was largest in spring, was correlated with winds $(\mathrm{r} \approx 0.6)$, and was mostly ( 50 to $75 \%$ ) forced by baroclinicity (Stabeno et al. in press). Occasional transport reversals (toward the NE) occurred when ageostrophic winds blew up Shelikof Strait. Although such local winds can amplify transport, many transport fluctuations are forced by large-scale storms pulsing the ACC. Ongoing studies of winds and currents in the area may further elucidate potential transport and mixing mechanisms. Winds and storms, through their effects on transport, have been shown to affect distribution (Checkley et al. 1988) and recruitment of other marine species (Roughgarden et al. 1988, Farrell et al. 1991, Koutsikopoulos et al. 1991).

We believe that it is significant that observed larval production was much lower than expected in 1986 and 1987. These are years when seasonal estimates of larval mortality were high $\left(0.08\right.$ to 0.26 and $0.11 \mathrm{~d}^{-1}$, respectively, for early stage larvae; Incze \& Campbell 1989, Incze et al. 1990, Yoklavich \& Bailey 1990. However, the 1987 mortality estimate was made from a period between 2 cruises, not covering the interval shown in Fig. 3d). Subsequent recruitment to these year classes was relatively poor (Hollowed \& Megrey $1990)$. On the other hand, 1988 was a year of low larval mortality $\left(0.04 \mathrm{~d}^{-1}\right.$; Hinckley et al. 1993), observed larval production was near to or above expected (from this study), and it resulted in the strongest year class 
since 1978 (Hollowed \& Megrey 1990). Our analysis shows that the period of successful larval production was extended in 1988 and corresponds to a protracted spring period of calm wind conditions. We propose that calm wind conditions when most first-feeding larvae were present in 1988 set up an initial situation of high larval survival, which, combined with benign conditions for later stages, resulted in the success of this year class. Other years, such as 1989, had relatively calmn wind conditions, but the period of high larval survival was relatively brief (the absolute numbers are difficult to compare because the late-surviving larvae in 1989 had not experienced much accumulated mortality), possibly due to factors other than wind, and later conditions may not have been as favorable during the late larval and juvenile stages.

Previous studies have linked calm wind conditions with strong recruitment to walleye pollock stocks in the Gulf of Alaska (Megrey et al. in press) and Bering Sea (Bailey et al. 1986). Warming periods with low storm activity and weak cyclonic circulation in the atmosphere were correlated with favorable recruitment to walleye pollock in the Sea of Okhotsk (Vasil'kov \& Glebova 1984). In Funka Bay, Japan, survival of walleye pollock larvae is believed to be closely linked to the timing of the spring bloom and circulation (Nakatani 1991). We would be surprised if the relationship of atmospheric conditions and recruitment to the fishery was consistent, because high larval survival rates appear to be a necessary, but not sufficient, condition for strong recruitment (Bailey \& Spring 1992) and year class strength can be altered by conditions during juvenile life. However, adverse wind conditions resulting in poor larval survival should be linked with predictable poor recruitment.

Experimental tests of hypotheses relating wind conditions and larval survival are desirable. However, the results of this study highlight some difficulties in making broad inferences about recruitment based on data from a limited number of field experiments. First, only 5 strong wind events and 10 medium events that significantly disrupted hatching success occurred during an 8 yr period. Without continuous, long-term. shiptime and monitoring of many variables, the probability of being in the field, at the right location, before, during and after one of these events is somewhat low. Second, relatively few calm periods resulted in strong survival success ( 9 of 27 ). Thus, a single experiment would have a $67 \%$ chance of sampling a calm period not associated with strong survival of larvae. A single hypothesis test conducted during one of these calm wind/poor survival periods could lead to the conclusion that calm winds are not beneficial to larval survival; that conclusion would be misleading since all strong survival periods were associated with calm winds.
Acknowledgements. We thank Drs J. Napp and N. Bond and 2 reviewers for their comments on the manuscript. We are especially indebted to $\mathrm{M}$. Yoklavich for otolith analyses and for valuable discussions, Annette Brown for otolith analyses, $K$. Meir for the power analysis, and S. Spring for assistance in data analysis. We also thank S. Picquelle for statistical advice, assistance in many phases of this project and comments on the manuscript, and Drs A. Kendall and J. Schumacher and other FOCI staff for their input and discussions. PMEL no. 1544. FOCI no. 0196.

\section{LITERATURE CITED}

Bailey, K. M. (1981). Larval transport and recruitment of Pacific hake Merluccius productus. Mar. Ecol. Prog. Ser. 6: $1-9$

Bailey, K. M., Francis, R. C., Schumacher, J. D. (1986). Recent information on the causes of variability in recruitment of Alaska pollock in the eastern Bering Sea: physical conditions and biological interactions. Int. North Pac. Fish. Comm. Bull. 47: 155-165

Bailey, K. M., Spring, S. M. (1992). Comparison of larval, age- 0 juvenile and age- 2 recruit abundance indices of walleye pollock, Theragra chalcogramma, in the western Gulf of Alaska. ICES J. mar. Sci. 49: 297-304

Bailey, K. M., Stehr, C. L. (1988). The effects of feeding periodicity and ration on the rate of increment formation in otoliths of larval walleye pollock Theragra chalcogramma (Pallas). J. exp. mar. Biol. Ecol. 122: 147-161

Bograd, S. J., Stabeno, P. J., Schumacher, J. D. (in press). A census of meoscale eddies on a continental shelf: Shelikof Strait, Alaska. J. geophys. Res.

Brown, A. B., Bailey, K. M. (1992). Otolith analysis of juvenile walleye pollock Theragra chalcogramma from the western Gulf of Alaska. Mar. Biol. 112: 23-30

Canino, M. F., Bailey, K. M., Incze, L. S. (1991). Temporal and geographic differences in feeding and nutritional condition of walleye pollock larvae Theragra chalcogramma in Shelikof Strait, Gulf of Alaska. Mar. Ecol. Prog. Ser. 79: $27-35$

Checkley, D. M., Raman, S., Maillet, G. L., Mason, K. M. (1988). Winter storm effects on the spawning and larval drift of a pelagic fish. Nature 335: $346-348$

Coombs, S. H., Nichols, J. H., Conway, D. V. P., Milligan, S., Halliday, N. C. (1992). Food availability for sprat larvae in the Irish Sea. J. mar. biol. Ass. U.K. 72: 821-834

Cox, D. R. (1955). Some statistical methods connected with series of events. J. R. stat. Soc. Ser. B 27: 129-157

Davis, C. S., Flierl, G. R., Wiebe, P. H., Franks, P. J. S. (1991). Micropatchiness, turbulence and recruitment in plankton. J. mar. Res 49: 109-151

Diel, S., Tande, K. (1992). Does the spawning of Calanus finmarchicus in high latitudes follow a reproducible pattern? Mar. Biol. 113: 21-31

Dunn, J. R., Rugen, W. C. (1989). A catalog of Northwest and Alaska Fisheries Center ichthyoplankton cruises 1965-88. NWAFC Processed Report No. 89-04, Alaska Fisheries Science Center, National Marine Fisheries Service. US Dept Commerce, Seattle

Farrell, T M., Bracher, D., Roughgarden, J. (1991). Crossshelf transport causes recruitment to intertidal populations in central California. Limnol. Oceanogr. 36: 279-288

Grant, W. S. Utter, F. M. (1980). Biochemical genetic variation in walleye pollock (Theragra chalcogramma) and population structure in the southeastern Bering Sea and Gulf of Alaska. Can. J. Fish. Aquat. Sci. 37 1093-1100 
Heath, M. (1989). A modelling and field study of grazing by herring larvae. Rapp. P.-v. Réun. Cons. int. Explor Mer 191: $233-247$

Hinckley, S., Bailey, K. M., Picquelle, S., Yoklavich, M., Stabeno, P. (1993). Age-specific mortality and transport of larval walleye pollock (Theragra chalcogramma) in the western Gulf of Alaska. Mar. Ecol. Prog. Ser. 98: 17-29

Hollowed, A. B., Megrey, B. (1990). Walleye pollock. In: Stock assessment and fishery evaluation report for the 1991 Gulf of Alaska groundfish fishery. North Pacific Fishery Management Council, Anchorage, p. 22-89

Huntsman, S. A., Barber, R. T (1977). Primary production off northwest Africa: the relationship to wind and nutrient conditions. Deep Sea Res. 24: 25-33

Incze, L. S., Campbell, D. E. (1989). Estimation of ichthyoplankton (Theragra chalcogramma) mortality rates from a patch study: FOCI 1986. Tech. Rep. No. 72. Bigelow Laboratory for Ocean Science, West Boothbay Harbor, ME

Incze, L. S., Kendall, A. W., Schumacher, J. D., Reed, R. K. (1989). Interactions of a mesoscale patch of larval fish (Theragra chalcogramma) with the Alaska Coastal Current. Cont. Shelf Res. 9: 269-284

Incze, L. S., Ortner, P. B., Schumacher, J. D. (1990). Microzooplankton, vertical mixing and advection in a larval fish patch. J. Plankton Res. 12: 365-379

Johnson, W. B. Jr (1966). The 'geotriptic' wind. Bull. Am Meteorol. Soc. 47: 982

Kendall, A. W. Jr, Picquelle, S. J. (1990). Egg and larval distributions of walleye pollock Theragra chalcogramma in Shelikof Strait, Gulf of Alaska. Fish. Bull. U.S. 88: 133-154

Kim, S., Kendall, A. W. Jr (1989). Distribution and transport of larval walleye pollock (Theragra chalcogramma) in Shelik of Strait, Gulf of Alaska, in relation to water movement. Rapp. P.-v. Réun. Cons. int. Explor. Mer 191: $127-136$

Kiorboe, T., Munk, P., Richardson, K., Christensen, V Paulsen, H. (1988). Plankton dynamics and larval herring growth, drift and survival in a frontal area. Mar. Ecol. Prog. Ser. 44: 205-219

Klein, P., Coste, B. (1984). Effects of wind-stress variability on nutrient transport into the mixed layer. Deep Sea Res $31: 21-37$

Koutsikopoulos, C., Fortier, L., Gagne, J. A. (1991). Crossshelf dispersion of Dover sole (Solea solea) eggs and larvae in Biscay Bay and recruitment to inshore nurseries. J. Plankton Res. 13: 923-945

Lackmann, G. M., Overland, J. E. (1989). Atmospheric structure and momentum balance during a gap-wind event in Shelikof Strait, A.laska. Mon. Weather Rev. 117: $1817-1833$

Lasker, R. (1975). Field criteria for survival of anchovy larvae the relation between inshore chlorophyll maximum layers and successful first feeding. Fish. Bull. U.S. 73: 453-462

Lough, R. G. (1984). Larval fish trophodynamic studies on Georges Bank: sampling strategy and initial results. In: Dahl, E., Danielssen, D. S., Moksness, E., Solemdal, P. (eds.) The propagation of cod. Flodevigen Rapp. 1: 395-434

MacKenzie, B. R., Leggett, W. C. (1991). Quantifying the contribution of small-scale turbulence to the encounter rates between larval fish and their zooplankton prey: effects of wind and tide. Mar. Ecol. Prog. Ser. 73: 149-160

Macklin, S. A., Stabeno, P. J., Schumacher, J D. (1993). A comparison of gradient and observed over-the-water winds along a mountainous coast. J. geophys. Res. 98: $16555-16569$

Maillet, G. L.., Checkley, D. M. (1991). Storm-related variation in the growth rate of otoliths of larval Atlantic menhaden
Brevoortia tyrannus: a time series analysis of biological and physical variables and implications for larva growth and mortality. Mar. Ecol. Prog. Ser. 79: 1-16

Megrey, B. A., Bograd, S. J., Rugen, W. C., Hollowed, A. B. Stabeno, P. J., Macklin, S. A., Schumacher, J D., Ingraham, W. J (in press). An exploratory analysis of associations between biotic and abiotic factors and year-class strength of Gulf of Alaska walleye pollock. Can. J. Fish. Aquat. Sci.

Mulligan, T. J., Chapman, R. W., Brown, B. L. (1992). Mitochondrial DNA analysis of walleye pollock, Theragra chalcogramma, from the eastern Bering Sea and Shelikof Strait, Gulf of Alaska. Can. J. Fish. Aquat. Sci. 49: 319-326

Mullin. M. M., Brooks, E. R., Reid, R. M. H., Napp, J., Stewart, E. F. (1985). Vertical structure of nearshore plankton off southern California: a storm and a larval fish food web. Fish. Bull. U.S. 83: 151-170

Nakatani, T. (1991). Copepod nauplii as food of walleye pollock larvae (Pisces: Gadidae) in Funka Bay, Japan. Bull. Plankton Soc. Japan Spec. Vol. 1991: 515-525

Niiler, P. P. (1977). One-dimensional models of the seasonal thermocline. In: Goldberg, E. D., McCave, I. N., O'Brien, J. J., Steele, J. H. (eds.) The sea, Vol. 6. John Wiley \& Sons, New York, p. 97-115

Nishimura, A., Yamada, J. (1984). Age and growth of larval and juvenile walleye pollock. Theragra chalcogramma (Pallas), as determined by otolith daily growth increments. J. exp. mar. Biol. Ecol. 82: 191-205

Norcross, B. L., Shaw, R. F. (1984). Oceanic and estuarine transport of fish eggs and larvae: a review. Trans. Am. Fish. Soc. 113: 153-165

Olla, B. L., Davis, M. W. (1990). Effects of physical factors on the vertical distribution of larval walleye pollock Theragra chalcogramma under controlled laboratory conditions. Mar. Ecol. Prog. Ser. 63: 105-112

Owen, R. W. (1989). Microscale and finescale variations of small plankton in coastal and pelagic environments. J. mar. Res. 47: 197-240

Peterman, R. M., Bradford, M. J. (1987). Wind speed and mortality rate of a marine fish, the northern anchovy (Engraulis Mordax). Science 235: 354-356

Picquelle, S. J., Megrey, B. A. (1993). A method of estimating spawning biomass from egg surveys with an application to walleye pollock, Theragra chalcogramma. Bull. mar. Sci. 53: $728-749$

Price, J F., Weller, R. A., Pinkel, R. (1986). Diurnal cycling: observations and models of the upper ocean response to diurnal heating, cooling, and wind mixing. J. geophys Res. 91. 8411-8427

Raymont, J. G. (1980). Plankton and productivity in the oceans, Vol. 1, 2nd edn. Pergamon Press, Oxford

Rothschild, B. J., Osborn, T. R. (1988). Small-scale turbulence and plankton contact rates. J. Plankton Res. 10: 465-474

Roughgarden, J., Gaines, S., Possingham, H. (1988). Recruitment dynamics in complex life cycles. Science 241: $1460-1466$

Schumacher, J. D., Kendall, A. W. Jr (1991). Some interactions between young walleye pollock and their environment in the western Gulf of Alaska. CalCOFI Rep. 32: 22-40

Shima, M., Bailey, K. M. (1994). Comparative analysis of ichthyoplankton sampling gear for early life stages of walleye pollock (Theragra chalcogramma). Fish. Oceanogr. 3: (in press)

Stabeno, P. J., Reed, R. K., Schumacher, J. D. (in press). The Alaska Coastal Current: continuity of forcing and transport. J. geophys. Res.

Sundby, S., Bjorke, H., Soldal, A. V., Olsen, S. (1989). Mor- 
tality rates during the early life stages and year-class strength of northeast Arctic cod (Gadus morhua L.). Rapp. P.-v. Réun. Cons. int. Explor. Mer 191: 351-358

Thresher, R. E., Harris, G. P., Gunn, J. S., Clementson, L. A. (1989). Phytoplankton production pulses and episodic settlement of a temperate marine fish. Nature 341: $641-643$

Vasil'kov, V P., Glebova, S. Yu. (1984). Factors determining year-class strength of the walleye pollock, Theragra chalcogramma (Gadidae), of western Kanchatka. J. Ichthyol. 24: $80-90$

Wilson, J. G., Overland, J. E. (1986). Meteorology. In: Hood, D. W., Zimmerman, S. (eds.) The Gulf of Alaska: physical environment and biological resources. Ocean Assess-

This article was submitted to the editor ments Division/NOAA, Anchorage, p. 31-54

Wooster, W. S., Bailey, K. M. (1989). Recruitment of marine fishes revisited. Spec. Publ. Can. Fish. Aquat. Scl. 108. $153-159$

Wroblewski, J. S., Richman, J. G. (1987). The non-linear response of plankton to wind mixing events - implications for survival of larval northern anchovy. J. Plankton Res. 9: 103-127

Yoklavich, M. M., Bailey, K. M. (1990). Hatching period, growth and survival of young walleye pollock Theragra chalcogramma as determined from otolith analysis. Mar Ecol. Prog. Ser. 64: 13-23

Zar, J. H. (1984). Biostatistical analysis. Prentice-Hall, Inc., Englewood Cliffs

Manuscript first received: November 19, 1993

Revised version accepted: July 13, 1994 